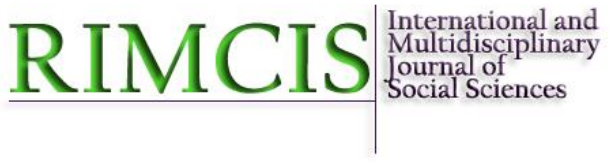

Hipatia Press

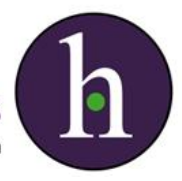

Instructions for authors, subscriptions and further details:

http://rimcis. hipatiapress.com

\title{
Accumulation Tendency, Sustainable Tourism and Hospitality in Tanzania
}

Evaristo Haulle ${ }^{1}$

1) Mkwawa University College of Education, University of Dar es Salaam.

Tanzania

Date of publication: March $30^{\text {th }}, 2019$

Edition period: March 2019 - July 2019

To cite this article: Haulle, E. (2019). Accumulation Tendency, Sustainable Tourism and Hospitality in Tanzania. International and Multidisciplinary Journal of Social Sciences, 8(1), 79-100 doi: 10.17583/rimcis.2019.3314

To link this article: http://doi.org/10.17583/rimcis.2019.3314

\section{PLEASE SCROLL DOWN FOR ARTICLE}

The terms and conditions of use are related to the Open Journal System and to Creative Commons Attribution License (CC-BY). 


\section{Accumulation Tendency, Sustainable Tourism and Hospitality in Tanzania}

Evaristo Haulle

University of Dar es Salaam

\section{Abstract}

Sustainable tourism depends on, among others, culture and interaction between members of a given community, flow of tourists and political climate of the host country, and hospitality of the service providers. It assumes that nature of the economy and relation of production and tranquillity define the sustainability of tourism. This paper presents the case of Ngorongoro district where Ngorongoro Conservation Area Authority (NCAA) and Loliondo Game Controlled Area (LGCA) are situated. Resources in these areas were sustained under the local community for centuries before the application of the modern approaches, which involved land alienation. The alienation of land led to the loss of pastures, eviction and relocation of Maasai pastoralists from NCAA. The situation made the pastoralists lose their livelihood options. Some development initiatives were prohibited. Community members started to fight with investors on access to resources. Moreover, search for alternative sources of living drove them into illegal practices of robbing travellers. Indeed, poaching and illegal transfers of wild animals by colluding with those in power made a few individuals benefit from the practices. As a result, the accumulation tendency made the hosting community lose their resources and the livelihood options as well. In this way, the only immediate option was trespassing to the existing resources and users; hence, malfunctioning of the sector. Thus, this paper argues that, in order to realise sustainable tourism and curb the emerging hostility between the resource hosts and the greedy individuals, community participation is paramount.

Keywords: tourism sustainability, hospitality, accumulation, Tanzania 


\title{
Tendencia de Acumulación, Turismo Sostenible y Hospitalidad en Tanzania
}

Evaristo Haulle

\author{
University of Dar es Salaam
}

\section{Resumen}

El turismo sostenible depende de, entre otras cosas, la cultura y la interacción entre los miembros de una determinada comunidad, el flujo de turistas, el clima político del país de acogida y de la hospitalidad de los proveedores de servicios. Asume que la naturaleza de la economía y la relación de producción y tranquilidad definen la sostenibilidad del turismo. Este artículo presenta el caso del distrito de Ngorongoro dónde se hallan la Autoridad del Área de Conservación del Ngorongoro (AACN) y el Área Controlada de Juego de Loliondo (ACJL). Los recursos en estas áreas se sostenían bajo la comunidad local durante muchos siglos antes de la aplicación del paradigma moderno que implica la alienación de la tierra. La alienación de la tierra condujo a la pérdida de pastos, deshaucios y realojamiento de los pastores Maasai del AACN. Esta situación les hizo perder a los pastores su medio de sustento. Algunas iniciativas de desarrollo fueron prohibidas. Los miembros de la comunidad empezaron a pelear con inversores sobre el acceso a los recursos. Más aún, la búsqueda de medios de vida alternativos les condujo a prácticas ilegales como el robo de turistas. En efecto, la caza furtiva y el tráfico ilegal de animales salvajes en connivencia con agentes en el poder benefició sólo a unos pocos. Como resultado, la tendencia de acumulación hizo perder a la comunidad de acogida sus recursos, así como sus medios de vida. En este sentido, la única opción inmediata era traspasar los usuarios y los recursos existentes; y por tanto, el mal funcionamiento del sector. Así este artículo argumenta que a fin de llevar a cabo un turismo sostenible y frenar la emergente hostilidad entre los dueños de los recursos y los individuos codiciosos, es primordial la participación de la comunidad.

Palabras clave: turismo sostenible, hospitalidad, acumulación, Tanzania

2019 Hipatia Press

ISSN: 2014-3680

DOI: $10.17583 /$ rimcis.2019.3314

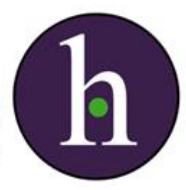




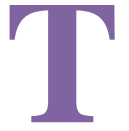

anzania is rich in natural resources such as mountains, forests, wetlands, wildlife, minerals, fresh and saline water, fisheries and many others. Such resources make Tanzania to be one of the countries with a lot of tourist attractions in the world (URT, 2009, 2015). The natural resources provide for Game reserves, National Parks, Marine Parks and reserves, mountains and Historical and Archaeological sites which are the tourist attractions in the country. This paper presents Ngorongoro district in Arusha region, Northern Tanzania as the case study. The district is endowed with various resources that are important for tourist attraction. The area has Ngorongoro Crater, which is one of the seven wonders of Africa and part of Ngorongoro Conservation Area (NCA) under Ngorongoro Conservation Area Authority (NCAA) (Haulle, 2014). The district has also game reserves, a series of lakes, mountains and historical and archaeological sites. The district is also situated in the Northern tourist circuit, which is powerful in attracting and bringing a good number of tourists. Some of these attractions in the vicinity of the district are: Mount Kilimanjaro, Tarangire, Arusha, Mkomazi, and Manyara National Parks. In particular, Ngorongoro district has four main tourist attractions, namely NCA, Serengeti National Park, Loliondo Game Controlled Area (LGCA) and Olduvai Gorge and Laetori historical sites. The Maasai and other minor ethnic groups of Datoga, Iraqwi, Sonjo and Waarusha who are basically pastoralists and agropastoralists occupy Ngorongoro district.

Tourism has been considered as an important sector that brings about development of any country. However, the concept of development has been questioned all time over the history. Questions such as what development, whose development and which forms of development have been recurring. Such questions imply that there is dissatisfaction of what is happening with or within the concept of development. In trying to answer such questions, other concepts like sustainable development, inclusive development, and broad base economy have emerged. In Tanzania, since independence, the question of development has been centred within capitalism as a worldwide process in different forms while accumulation being at the centre of the analysis. This paper, therefore, tries to analyse tourism sector, in particular creation and operation of tourism amenities in relation to benefits obtained and its challenges. The paper principally intends to contribute to the role of 
the community involvement in resource governance as one of the important drivers for sustainable development. In this case, the challenges mainly recur as a result of alienation of majority members of the community in active resource governance.

Accumulation tendency is a historical process of separating the producers from the means of production (Sewell et al., 2007). The separation ensures existence of wage labour, and, therefore, it is a fundamental condition of capitalist production. The process can be achieved through two ways: normal economic means which are the result of the expanded production normally called primitive accumulation, and extra economic forces which are also considered as accumulation by dispossession which promotes the primitive accumulation (Shivji, 2006). The concept implies that differences in human development are the results of human processes and the human creation at large. However, this idea of human creation is contrary to assumptions of capitalism that people were naturally born rich, and others poor (Shivji, 2009). Nature did not produce property-less labourers and the owner of the property.

The capitalism operation is entrenched in the myth of the marketplace, which has actually made the market to be the universal solution. It means that everything is a commodity and can be priced at the market. The neoliberal construct has been the global wisdom and common sense. Whenever the market did not exist like in-land, water, environment, human security, health and education, then such markets were to be created (Shivji, 2009). This is because the role of the state is to create the framework and institutions appropriate for such a process. The responsibility of the state is to discourage collective property, national development and social solidarity or trade unionism by championing and perpetuating individualism. This is clearly stated within the concept of Desotho on the Mystery of Capital when he tried to bring life to the dead capital, land. The third president of Tanzania used Desotho's book as a holy book for his cabinet to make a market where there was no market.

There are five characteristics of neo-liberalism, which are: first, commodification and privatisation; second, pervasive nature of predatory and speculative financialisation of capital; third, militarisation; fourth, polarisation - uneven distribution of wealth and fifth, the ephemerality of 
relations and shortening time horizon (lack of job security and human respect). These characteristics have influenced accumulation. In order to connect accumulation with tourism, it is important to understand the concept of tourism and sustainable tourism.

'Sustainable Tourism' and 'Sustainable development' through tourism are used interchangeably though they are complex concepts due to their latent, multidimensional and relative nature. For tourism to be considered sustainable, the objectives need to be well defined and coordinated by effective management system (Burghelea, 2015). Tourism is also expected to bring the greatest possible socio-economic benefits for local communities and minimise any adverse impact on human and environment. Again, for tourism to be considered sustainable, it needs responsible tourism. In this case, the concept tries to answer the questions about who uses what and how? What is collected and what is spent for whose interests? The most important thing is how these tourist centres are established and managed.

\section{Methodology}

The study employed historical approach in understanding tourism practices in Tanzania. It presents Ngorongoro district as a case study. In this district, Ngorongoro Conservation Area (NCA) and Loliondo Game Controlled Area (LGCA) were analysed. The areas were selected due to the fact that they encompass the early-protected natural areas of Tanzania. The choice was also informed by the fact that these areas have unique biodiversity for which conservation and human life have been believed to exist in harmony; animals and human live side by side. The area is also famous in tourism globally. This is because UNESCO and IUCEA recognise NCA as the World Heritage and Biosphere Site respectively. The study employed documentary search technique to obtain relevant information for the present study. In this way, research and media reports, policy documents, government reports and scholarly publications were scrutinized. Their contents were analysed in relation to the context of the present study. The online and library resources in hardcopies were included in the study. 


\section{Contribution of Tourism in Tanzania}

Tourism has contributed to the improvement of human livelihoods and national income. The increase in expenditure, numbers of visitors, and time spent in the country has had a bearing on the national income. According to Menezes et al. (2010), the length of stay since 2002 was on average of 10 to 11 days. The length of stay determines the expenditure, the earning and thus the overall performance of the sector. By 1978, the length of stay was about three days. However, in 1990s, there occurred a sharp increase in the length of stay from three to 12 days in 2012. The question here is, where did they spend the fund? Who owns the premise or the business?

Besides, reports have shown that tourism sector contributes to GDP and the trend has been increasing since 1990s. The percentage grew from $2.1 \%$ in 1990 to $13.1 \%$ in 2012. In comparison with world average, Tanzania is far behind the target. For instance, when Tanzania performed well, the sector contributed to GDP up to $13.1 \%$. This was only $8 \%$ of the world average, which amounted to $\$ 52$ billion. This, indeed, indicates that the world average was 13 times the contribution of Tanzania. Tanzania being one of the 56 poorest countries had shown that tourism is among the most important sectors for socio-economic change of its people (Buzinde et al., 2014). Yet, its contribution is still very low. It was reported that there was an increase of employment after the liberalization. In 1990, there were 99,000 employment opportunities, which were equivalent to $1.8 \%$ of employees, and 547,600 in 2000, which was equivalent to $7.3 \%$ (Bush, 2009). By contrast, in 2012, the employment increased to 1.2 million (11.4\%). This was the increase of 12 folds from 1990 to 2012 (WTTC, 2012). However, the total employment increased by $2.4 \%$ per annum, which is similar to what Mkinga, (2012) observed.

In many developed countries, tourism is considered a continuum anchored by "Tourism first" which implies the maximisation of economic impact and growth while maintaining cultural and environmental goals. In this manner, the well being of the community becomes the opportunity cost to development. When the community becomes an opportunity cost, it also implies putting the idea of Magreth Thatcher into practice, that there is nothing like the society, only individuals exist sound to be the conventional 
wisdom. This conventional wisdom is discussed in many studies such as Mkinga (2012) and Donath (2013) that advocate tourism industry; yet ignore to consider the adverse impacts to the community. They only focus on the economic gains which are also not questioned about whether they serve the interest of the mass or of a few individuals who own the enterprises to make sure that the profit is transferred to the north again.

Table 1.

Tourist Arrivals versus Earnings

\begin{tabular}{ccc} 
Year & Number of Visitors & Earnings (Mill USD) \\
\hline 1961 & 12,218 & 13.39 \\
1980 & 84,021 & 19.75 \\
1990 & 135,000 & 65.00 \\
2000 & 501,669 & 739.00 \\
2010 & 782,699 & $1,254.50$ \\
2016 & $1,284,279$ & $2,131.57$ \\
\hline
\end{tabular}

Source: Donath (2013), URT (2017)

\section{Historical Development of Tourism and Land issues in Tanzania}

The German colonial rule in 1891 marked the beginning of game conservation in Tanzania when the laws to mitigate irresponsible hunting were established. This was followed by the establishment of game reserves in the present Selous Game Reserve in 1905 (URT, 1998). These laws regulated the off take, hunting methods and the trade in wildlife. In 1921, the British government established game department followed by gazetting of Selous Game Reserve in 1922. Later on, the Ngorongoro crater was closed in 1928, and Serengeti Game Reserve was established in 1929.

German rule marked the beginning of tourism by establishing two Game Reserves in 1910. The first was the Saba Game Reserve, which was renamed by British as Rungwa Game Reserve in 1946. The reserve forms part of the present Ruaha National Park, which is the largest in Tanzania and the second in Africa (TTB, 2015). The park was gazetted in 1964. The second reserve was Kilimanjaro reserve, which is now Kilimanjaro National Park (KINAPA). The Kilimanjaro reserve was gazetted in 1973 and was declared the World Heritage in 1987 and named among the seven wonders of Africa 
in 2010. During the British colonialism many Parks and Game reserves were established as championed by Selous Game Reserve found in southern Tanzania and acquired the World Heritage status of the World Game Sanctuary in 1982 (URT, 2015).

For the purpose of improving tourism and making it more productive and economically viable, commercial tourism was introduced in Tanzania during the British regime. East Africa Publicity Association (EAPA) was established in 1938 for the purpose of stimulating tourism in the region. This was possible as the whole of East African was under British colonialism. The Association was based in Nairobi (TTB, 2015). The organ was changed in 1948 when East Africa Tourist Travel Association (EATTA) was established. EATTA had a duty of coordinating all matters relating to tourism promotion and operation in the region. EATTA operated till 1965.

The independent Tanzania advanced the wheel by establishing the Ministry of Information and Tourism in 1964. Since then, tourism has undergone a series of changes, and, to date it is a division under the Ministry of Natural Resources and Tourism. Tourism was more advanced by establishing Tanzania Tourism Board (TTB). The Board has been tasked to advertise Tanzania as a popular tourist destination and be encouraged to take such measures as it may deem fit for the development of such amenities in Tanzania that it may enhance attractiveness of Tanzania to tourist. It has also a duty to make such inquires; and collection of all pertinent information as it may deem necessary for the purpose of carrying out its function, among others.

Tourism as an activity started with the coming of foreigners from the West and the Middle East (TTB, 2015). They came as explorers, missionaries or businessmen. However, tourism is considered to have started officially when the official organ that deals with tourism promotion was established. The organ was established after the establishment of National Park's Game Reserve and some historical sites. In 1946, hunting blocks under game controlled area were established, and thus, the trophy hunting officially started. During the independence, Tanzania had only three national parks and nine games as controlled areas compared to 17 and 34, which are present to date respectively. To date, Tanzania is said to be the leading 
country in attracting tourists in Africa (URT, 2015a). However, it should be noted that it is the leading country in poaching as well.

The establishment of tourist sites has direct relationship with land use. During the pre-colonial era, the people owned the land of Tanganyika, unlike during the German era where all land was declared to be a crown land. In Imperial $26^{\text {th }}$ November 1895 Decree that all the land of Tanganyika was declared crown land vested under the German empire made the people on the said land to lose their sovereignty and means of production altogether. In 1923 when British established the land ordinance, the same was emphasised. The land was transferred from the Germans to British without any discussion or consent from the natives. The natives became tenants in their own land. This change of law describes the massive land grab ever experienced in Tanzania.

Acquisition of land from the Tanzanians by colonialists helped the colonisers to appropriate wealth through direct production on land and indirectly through what could be done on land. The law, again, helped them to use any land provided that it was under the governor for the interest of the governor. The establishment of national parks and reserves was made immediately after appropriation of land from people to the state. The state was there to maintain the status quo of the ruling class.

On similar grounds, J. K Nyerere the founding father of Tanzania in the government paper of 1958 published what he referred to as "Mali ya Umma" means collective wealth referring to land that was grabbed by the state. During the struggle for independence, such acts were strongly condemned. The act was condemned for prohibiting freedom of people economically, politically and socially, while the land was crucial to the poor communities as it could act as the base for development. However, post-independence land reforms did not change land tenure systems. The land remained under the state bureaucrats (Shivji \& Kapinga, 1998; Haulle, 2015). Even after 50 years of independence of Tanzania, the land tenure system still had to follow the base that was set by German colonial masters on $26^{\text {th }}$ November 1895 and as advanced by British rule in 1923.

The implementation of Arusha declaration in general and villagelisation "Sogeza" was made possible due to the fact that the state rather than people owned all land. Establishment of state companies that depended on land 
resources like National Ranches, National food companies, reserve and conservation areas was made simple due to nature of land tenure system that existed in Tanzania. The formation of national parks and reserves was among the major grievances raised by the people to the presidential commission of inquiry on land matters (Shivji \& Ally, 2011). The situation could be rather difficult if it was compared with that of Uganda Buganda factor in Uganda Politics where the Kabaka of Buganda owned land to the extent that the state had no sufficient land.

It should be noted that though the land in Tanzania has been decelerated, it is owned by public under the trusteeship of the president. In fact, the president is an executive and head of the state. He has a freehold title of land. He has the power to grant and revoke any offer and Right of occupancy. Any land user in Tanzania is just like a tenant on land. The trustee in the name of public interest can do anything. Public interest means the interest of the state (Shivji, 2006). In view of this, the proper performance of tourism sector depends much on how land tenure system is set and governed and how these tourist attractions are established.

\section{Investment Trend in relation to broad base Economy}

Tanzania started implementation of Structural Adjustment Programmes (SAPs) during the last four decades, which was the era of neoliberalism. Tourism sector has, since then, been expanded in terms of its investment, returns to the economy. Following liberalisation, the Foreign Direct Investment (FDI) has increased as well implying that it captured the interest of the western. Donath (2013) reported that in Tanzania FDI has increased from USD 10 million (06\% of total investment) in 1990 to USD 10 billion (22 3.5\% of total investment) in 2000 and to USD 879 million (102\% of total investment) in 2012. This was not a coincidence, rather the global trend towards least developing states especially on the epoch post-the lost decade on Africa in 1980s. Africa had experienced a steady rise of FDI though very little was directed in production. Most of FDI was injected into administrative costs while little portion was directed to production and services. Thus, the economy would still be unstable, and its stability depends on the economy of the producers. 
About $70 \%$ of European Union aid to developing countries supports private sector to create climate/environment conducive to investment. The support is mainly directed to the advancement of private public partnership. According to Curtis in Bond (2006), this kind of support is the major investment opportunities for European companies. More often, this ends up financing their own companies working in Africa in collaboration with a few individuals who normally have ties with the state. This implies that the little that is remaining is used to support the comprador class in Africa, which will be taken back through other mechanisms (Shivji, 2009). Such mechanisms include debt servicing, unfavourable Terms of Trade (ToT), unfavourable Balance of Payment (BoP) and false treaties with multinational and transnational. The nature of the investment in Tanzania explains the disarticulated economy; thus, the accumulation in African periphery. From 1986 to 1990, Africa lost about $\$ 50$ billion through the decline of the price of the exported goods (Bond, 2006). It also experienced unfavourable terms of trade and balance of payment. Ultimately, it is the poor people who would bare that burden of the exploited surplus. Resistance is always the last resort that the poor has after when he/she finds that no option for his survival is available.

In that way, whatever is done may not be for good will. For example, most of the developed countries spend more in military than what is directed to the aid which Africa is banking on. It is evident that in 2003, for example, the rich countries spent about 642 billion for military and 69 billion for aid in Africa. Some of the specific examples of military spending are provided and the aid proportion to the GDP in brackets: US $-25 \%(1 \%-1.4 \%)$, Greece 16.5\% (1\%), France 10.7\% (1.7\%) and Portugal 10\% (1\%) (Bond 2006). This makes the US and France the major phantom donors, while the US and Italy are the most tied aid offenders. It also explains the nature of militarism being one of the major characteristics of globalised neoliberalism. These hegemonic states provide support in resource extraction, while grinding their military teeth at the same time. Bread and the gun are brought at the same time, while taking away oil, gold and uranium. In such crisis, can a sense of hospitality be felt? 


\section{National Parks and Game Reserves}

National Parks and Game Reserves are among the main tourist attractions in Tanzania. They cover extensive part of Tanzania and are the main sources of income generated from tourism attractions. To date, generally, about one third of Tanzania is under protection of one form or another. Ngorongoro is among the districts, which are much affected by conservation for tourism in Tanzania. About two-third of the district is under conservation. Tourist attraction in this district depends much on wildlife-conserved areas, small landscape scenery and a few archaeological sites. Historically, the area has been resided by agro-pastoralist, Datoga who are cushites by nature of Iraq ethic group for about 2000 years. They were farming as defined in the NCA (Shivji \& Kapinga, 1998). However, later on, there came the Maasai who were pastoralists. For about four centuries, they used the Serengeti Ecosystem for grazing (Haulle, 2015). In this way, the name Serengeti was delivered from Ma "Siringit" meaning endless land. It was reported that the first foreigner came in this land in 1700s and saw the area as habited and used.

This plot of land was parcelled to suit different land users giving priority to tourism while ignoring the interests of the Maasai and Datoga who are found in the area (Haulle, 2014). This is the main reason why the kindness and hospitality that is praised to Tanzania cannot be deeply felt in such environment.

The beginning of conservation in Ngorongoro can be traced back in 1928 when the houses were established by German settlers in the northern edge of NCA closer to the boundary of Serengeti National Park. Serengeti National Park was also established in slicing a portion of Maasai block of pastureland (Shivji, 1998; Shivji \& Kapinga, 1998; URT, 2015). The people were not allowed to stay in this area anymore. In 1959, Ngorongoro Conservation Area was established by the Parliament Ordinance, which is now referred to as CAP 284 (Revised Edition of 2002) (URT, 2002a). After experiencing the difficulties and bitterness of the Maasai on land use, in April 1958 the Colonial government entered false agreement with Maasai laigwanans to accept the prohibition to trespass the Serengeti National Park. In this agreement Maasai were to use the present NCA as their homeland and 
pastures. In 1959, NCA was established, and, thereafter, the Maasai livelihoods were regulated to suit the conservation demands.

NCA was given the World Biosphere Reserve status and World Heritage site in 1979 by IUCN. This status was another impediment to Maasai residents in the area because new conditions and laws were introduced. Nowadays, NCAA claims that the Maasai are depleting the environment, and, therefore, the relocation outside NCA is the ultimate option. Many people were removed from NCA especially from Nayobi, Nainokanoka and Malambo to Oldoinyo Sambu. In 2012, about 200 families were relocated from the NCA. It should also be noted that in the NCA there were few Maasai bomas, which are considered for cultural tourism. These bomas and maintenance of the Maasai livelihood standards attracts a lot of tourists thus bringing a lot of revenue as well. When the Maasai population increased and improved their living standards, the international community threatened to renounce NCA as the World Heritage in 2010.

Ngorongoro district also has one of the famous GCAs known as Loliondo Game Controlled Area (LGCA). LGCA is characterised by the presence of Cornel hunting companies including Thomson Safaris, Andrew and Ortles Business Company (OBC). The companies deal with commercial hunting and photographic tourism. It is clear that there was no negotiation upon their imposition in the area. It is important to note that such villages were registered under the village act of 1975 and protected by village land Act No. 5 of 1999 (URT 2002b, 2002c, 2002d). Being registered villages, it means that they have jurisdictions over their land and all the land under their jurisdiction were to be used by the consent of the village.

The villagers quarrelled with Thomson Safari when they noted that the area of Thomson Safari increased to $4000 \mathrm{~km}^{2}$ without notice year after year. Furthermore, people were prohibited to use water points found in the area for their livestock and domestic purposes. The water points were said to be under the Thomson Safaris. This caused misunderstanding in 2009 through 2010.

The hunting companies acquired the hunting blocks through central government and thus local people have no power to either prohibit or control them. This area was previously resided by people, but, in 2013, the Ministry in charge of conservation decided to relocate 48,000 people who settled in 
LGCA. The people revealed that the aim of the Ministry was to acquire more land for turning it to be part of game reserve. It should also be noted that, before the new Act of wildlife conservation, people were allowed to settle in GCAs. The ministry claimed to relocate these people because they encroached into water catchments and re-establish the wildlife corridor while releasing about $1500 \mathrm{Km}^{2}$ from the LGCA to be used for human activities. It was revealed that the government was looking for the establishment of the corridor for OBC hunting activities. This means increasing tourism activities and hence, increasing revenue. The situation caused the outbreak of conflict between the state and the local community. One of the local leaders was quoted saying:

"For us, our land is everything, but these Arab princes have no respect for the animals or our rights. Many of us would rather die than be forced to move again." Another local pastoralist and campaigner, " 1500 square $\mathrm{km}$ for these Arabs!! This is a shock.....the government is telling us to compromise but people say they have given up enough. Giving up the Serengeti national park was a lifelong compromise then. They will not be pushed again" (Haulle, 2014).

It is also important to note that within NCA and LGCA, there are villages that were officially registered in 1970s while knowing the nature and status of such environment (Haulle, 2014). The registration of villages is also posing contradiction between the jurisdiction of the village against that of the NCAA and LGCA whose power is derived direct from the president who has a radical title. In such contradictions, it is implied that the announcement of reserve areas and registration of villages cause double allocation problem. The contradiction caused conflicts among these different users and thus, raised hostility. In such situation of hostility, those few community members who enjoy the benefits of the natural resources would be considered instigators, and, therefore, the anger of the mass might burn against them. Nevertheless, the hostility may be extended to visitors and thus, causing robing and injury to the people. In this case, hospitality is questionable. This is the witness that a lot of newspaper stories have been written showing or implying Tourism is a curse to Maasai. This is also bringing in to the general concept of resource curse in Africa. 
These two conserved areas, which are the source of revenue to the government, were several times reported to be involved in corruption and squandering public fund. Moreover, these areas have been implicated with the shipping of live animals to Arab and other parts of the world illegally. Similarly, due to shortage of land for human livelihood options, due to poor ways of engagement and holding the land- land grabbing, the conflict between land users in the area have been the order of the day. People are peaceful no more. Even the researchers have been attacked conceived to be part of the state and private sector that grab their land. People become sceptical with any visitor. Any visitor has been the source or a continuum of the community poverty, lack of freedom and tranquillity. Some of the researchers have survived while we have the evidence of researchers being killed as they were researching for soil resources in Dodoma in October 2016.

\section{Management of Tourist Attractions}

Tourism sector guidelines like tourism policy are the result of the highly politicised process of identifying relevant issues, agenda and setting and deliberation about who is involved in and affected by development (Bramwell \& Lane, 2011; Stumpf \& Swanger, 2014). Being highly politicised in the context of comprador state, it means that the process will be fulfilling the interest of the capitalist state. Similarly, Strumpf and Swanger (2014), argue that there is no such thing like policy formulation in developing states of this kind instead there is policy customisation, diffusion and conformity and of course conforming to the north and western interest. While institutions are strengthened, poaching is on increase year after year. For instance, in 2013/14, about 391 poachers were caught and 164 were convicted. In operation tokomeza (anti-poaching operation) alone, about 2,085 people who were alleged to be poachers were caught (URT, 2014).

It should also be noted that majority of the people who live in the vicinity of National Parks and game controlled areas have continued to experience a loss caused by tourist attractions especially animals. For instance, in 2013/14 about 19 people were killed by wild animals and 4,345.8 acres of crops were destroyed (URT, 2015a). The respective authority paid about Tsh 485,000 
(Approximately US \$220) per person who lost his/her life. When considering the fines imposed to a person killing wild animal by accident only two fines of animals are less than the compensation of human life i.e. baboon and civet cat which $\$ 110$ and $\$ 200$ respectively (see figure 1). The compensation to crops destroyed was Tsh. 98.4 million, which is equivalent to Tshs. 22, 642 (Approximately US \$10.3) per acre. Similarly, when considering the price of maize in the local market Tshs. 22, 642 can only buy about $22 \mathrm{~kg}$ of maize flour, which is a staple food in Tanzania. According to household and population census of 2012, the family size in Tanzania is approximately to 5.8 (URT, 2013). This sum which was provided as a compensation would be sufficient to support the living in less than a week for a family and less than a month for a person.

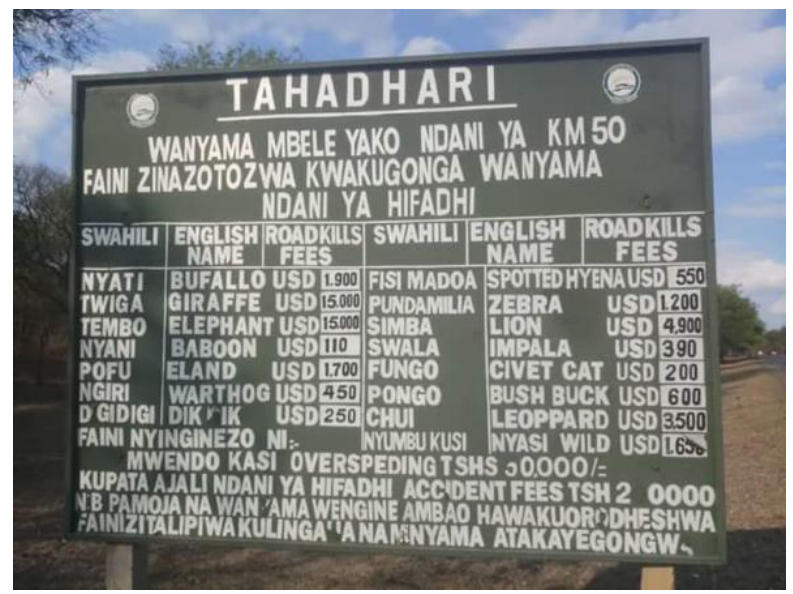

Figure 1. Signpost showing the penalty associated by killing some animals by road accident in national parks in Tanzania

According to Mkinga (2012), tourism is an additional diversification option for the poor, not a substitute for their activities. Tourism can generate fund for investment into other sectors. It is associated with several gains, which are considered to be financial, social, and empowerment. The most important to note when people opt for substitution; it means that there was insufficiencies in the main option. Mkinga (2012), shows that sustainable 
tourism is constrained with a number of impediments mainly being inadequate education, skills and financial capabilities and poor transportation. It is argued that Africa is facing limitation in funding roads improvement for tourism expansion (Mkinga, 2012). However, Mkinga is not looking for adverse impacts caused by the tourism sector. These include the rise of cost of living to local people in tourist centres. In relation to what was considered to be lack of capacity the sector is employing about only $2 \%$ of the labour force while majority of tour guide are not local, they should learn language of the tourist. This is the same neo liberal agenda that insist that Africa is experiencing lack of capacity. African is in the same depression of lack of capacity to enhance tourism hence needs technological assistance. This rhetoric has been the justification for technical Assistant, which is equivalent to $50 \%$ of the total aid provided in Africa (Bush, 2009). This exemplify that tourism is the consumption of what is not produced as one of the main characteristics of disarticulated economy. This is known as disarticulation of the structure of production and consumption (Shivji, 2009).

\section{Effects of Accumulation Tendency}

The land grabbling that is experienced through history has caused numerous effects that are relating to the decline of hospitality. Land has been the source of life of humankind in Africa. Whenever there is alienation or detachment from land, automatically the human functioning will have to change to the worse. The accumulation through land grab has caused many people in Ngorongoro District to become landless. Their livelihoods became at risk due to the fact that their living depends on land. People are relocated by force and to collaboration or lobbing. When other users use this land, while the citizen become wonderers and the hatred to visitors must be escalated and, therefore, limited support will be given to visitors. This is because their livelihoods are at risk and thinking that this has been caused by creation of a space for foreigners who will provide foreign currency for the Country. In order to overcome this situation, the people have adjusted themselves to segregation on resource access due to the fact that local people will not retrieve the appropriated resources; thus, price differentiation between foreigners and nationals has been a reactionary response. Most of 
the people offer higher price to visitors against the citizens. The special price provided to foreigners in social services, which is popularly known as mzungu price, becomes a survival strategy to local population hence tourism sector sustainability and hospitality is questionable.

Due to the loss of stable livelihoods some of the people have turned to robbery. Many visitors have lost their property and life through armed or unarmed robbery. In some cases when they were faced in accident, instead of getting rescue people rush to take their possessions for survival strategy. The accumulation tendency has concentrated power and resource into few. For example, the conservator has very strong discretion power over NCA to the extent that only few can be involved in decision-making and, therefore, abuse of power and embezzlement of resources are obvious. This is justified with the allegations that many NCA officials were forced out of office due to corruption. For example, in March 15, 2016, the Minister for Natural Resources and Tourism as he then was suspended five NCAA Body officials while 15 others were transferred due to such misconducts (The Citizen, 2016).

Some people were brutalised and their houses were burnt down by the use of excessive power vested to conservation units and District and regional officials. Many houses were burnt down in Nyamuswa in Serengeti in 2006 and in Ngorongoro district in 2009 by the order of the district official in the name of public interest while protecting the interested of the tourist investors.

Poaching is tremendously increasing nowadays than before. A lot of both of animals \& plants species have been endangered and threatened (Kamata, 2008). It was also reported in the Parliament of Tanzaniathat152 live animals including four giraffes were illegally transferred to Doha by Qatar army jet through Kilimanjaro International Airport in 26 ${ }^{\text {th }}$ November 2010 (The Mwananchi, 2014). Bio-piracy is now leading in terms of physical transfer and even with support of Intellectual property through unguided research. In the situation where the residents are not benefiting with the resources in their vicinity, how can the hospitality be maintained?

Rhinos are now wealth more than diamond. The Maasai who were for quite sometimes considered to live in harmony with wildlife have now turned to be hostile. They poach for market purposes as well as sustaining 
their living. This is because the Maasai have been denied ownership of such resources to the extent that management of wildlife becomes a curse to them. Tourism and wildlife in Tanzania can simply be said to be a resource curse. The management approaches are considered to emphasis the wildlife than human kind. This is also exemplified by the way the government agencies are advertising such resources as the priority is seen to be in wildlife while humankind is the last (Kamata, 2008).

\section{Conclusion and Recommendations}

Land is a very important resource to eco-tourism maintenance. It is from this absolute space eco-tourism can be developed. Moreover, its sustainability depends much on rational space and the way people relates with space. For this case, land tenure system has a great role to play in defining such space. Conflicts that are experienced in Ngorongoro district; robbery, poaching and other behaviours that are against human hospitality which is a base for sustainable tourism are associated directly with livelihood options and land tenure system which are in principle a rational space. The system that has made most of the citizen to be passive and recipient of development plans. Objectification of human and their livelihood options reduce harmony and fragility, which are important for tourism. It is a resource curse to the local people in the Ngorongoro district.

It is, thus, recommended that there is a need for reviewing land tenure system. The lost power of citizen over their land should be restored. The power that was grabbled in 1890 has never been restored. The review of land tenure system should go hand in hand with expansion of people participation in decision-making. Participatory land use planning is very important in order to attain the consent of the community and accommodate all kind of land uses and land users and find common solution to the existing and anticipated challenges.

Equity in distribution of resources is very important in sustaining tourism. The neighbouring communities need to benefit from the revenue collected from their resources. Furthermore, the standards of living of the local people in the vicinity of any resources should be improved. The improvement of livelihoods will reduce trespass and depletion of resources. 
Through these initiatives, the sense of ownership will be experienced; hence, hospitality and sustainability will be felt. Government needs to make sure the public fund from whatever source is not squandered. There should be a proper distribution and use of public fund so as to encourage people to maintain natural resources for the benefit of the whole community.

\section{References}

Bond, P. (2006). Looting Africa: The economics of exploitation. London, Zed books.

Bramwell, B., \& Lane, B. (2011). Critical Research on the Governance of Tourism and Sustainability. Journal of Sustainable Tourism, 19(4-5), 411-421. doi: 10.1080/09669582.2011.580586

Burghelea, C. (2015). Analysis of Sustainable Tourism in Romania. Internal Auditing and Risk Management, 1(37).

Bush, R. (2009). The land and the People. In R. El-Mahdi \& P. Marfleet (eds), Egypt; The Movement of Change. London, Zedbooks.

Buzinde, C.N., Kalavar, J.M., \& Melubo, K. (2014). Tourism and Community Well-being: the case of the Maasai in Tanzania. Annals of Tourism Research, 44, 20- 35. doi: 10.1016/j.annals.2013.08.010

Donath, L. (2013). International Demand for Tanzania Tourism: Evidence from Panel Data, M.A. (Economics) Dissertation, Dar es Salaam, University of Dar es Salaam.

Haulle, E. (2014). Assessment of Communities`Coping Mechanisms to Geodisaster Risks in the Vicinity of Oldoinyo Lengai in Northern Tanzania, PhD Thesis, Dar es Salaam, University of Dar es Salaam.

Haulle, E. (2015). Land Resource in Tanzania; Whose State, whose Resource? International Journal of Social Science Studies, 3(6), 7078. doi: 10.11114/ijsss.v3i6.1102

Kamata, N. (2008). The Mute Plunder; Bioresources and Dispossession in Tanzania. Dar es Salaam, HAKIARDHI.

Menezes, A., Moniz, A., \& Vieira, J.C. (2010). The determinants of length of stay of tourists in the Azores. Nta-Delgada, University of Azores and CEEAplA, Rua da Mãe de Deus. 
Mkinga, N.I. (2012). Assessment of Tourism Associated Activities for Rural Livelihood Transformation. Utafiti Journal of the College of Arts and Social Sciences, 9(1-2).

Sewell, R., Brooks, M., \& Woods, A. (2007). What is Marxism? London. Wellred Publications.

Shivji, I.G. (1998). Not yet Democracy: Reforming Land Tenure in Tanzania. Dar es Salaam: HAKIARDHI.

Shivji, I.G. (2006). Lawyers in Neoliberalism: Authority's Professional Supplicants or Society's Amateurish Conscience. Veladictory on the occasion of formal retirement from the University of Dar es Salaam.

Dar es Salaam: Faculty of Law, University of Dar es Salaam.

Shivji, I.G. (2009). Accumulation in an African Periphery: A Theoretical

Framework. Dar es Salaam/ Harare, Mkuki na Nyota Publishers/African Institute for Agrarian Studies.

Shivji, I.G., \& Kapinga, W.B. (1998). Maasai Rights in Ngorongoro, Tanzania. Dar es Salaam: HAKI ARDHI.

Shivji, I.G., \& Ally, B. (2011). Insha za Mapambano ya Wanyonge. Dar es Salaam: Taasisi yaTaaluma za Kiswahili.

Stumpf, T.S., \& Swanger, N. (2014). Tourism involvement - conformance theory. A grounded theory concerning the latent consequences of sustainable tourism policy shifts. Journal of Sustainable Tourism, 23 (4), 618-631. doi: 10.1080/09669582.2014.959967

The Citizen (2016, March 5). Maghembe suspends five NCAA body officials. The Citizen. Retrieved from http://www.thecitizen.co.tz

The Mwananchi (2014, May 16). Sakata la Kutorosha wanyama hai Kwenda Qatar laibuliwa Bungeni. Mwananchi. Retrieved from https://mobile.mwananchi.co.tz/

TTB (2015). Tanzania Tourist Board. Retrieved from www.tanzaniatouristboard.com

URT (1998). The Wildlife Policy of Tanzania. Dar es Salaam: Ministry of Natural Resources and Tourism.

URT (2002a). Ngorongoro Conservation Area Ordinance Cap 413. Dar es Salaam: The Parliament of United Republic of Tanzania.

URT (2002b). Local Government District Authority Act of 1982 CAP 287.

Dar es Salaam: The Parliament of United Republic of Tanzania. 
100 Haulle - Sustainable Tourism in Tanzania

URT (2002c). Land Act No 4. Dar es Salaam: The Parliament of United Republic of Tanzania.

URT (2002d). Village Land Act No 5. Dar es Salaam: The Parliament of United Republic of Tanzania.

URT (2006). Ngorongoro Conservation Area: General Management Plan 2006-2016. Dar es Salaam: Ministry of Natural Resources and Tourism.

URT (2009). Wildlife Conservation Act no 5 of 2009. Dar es Salaam: The Parliament of United Republic of Tanzania,

URT (2013). Population and Housing Census: Population distribution by Administrative Areas. Dar es Salaam: National Bureau of Statistics.

URT (2013a). Taarifa ya Kamati ya Kudumu ya Bunge ya Ardhi, Maliasili na Mazingira Kuhusu Tathmini ya Matatizo Yaliotokana na Operesheni Tokomeza. Dodoma: Bunge la Jamhuri ya Muungano wa Tanzania.

URT (2014). Hotuba ya Waziri wa Maliasili na Utalii Mh. Lazaro Samweli Nyarandu (Mb) Akiwasilisha Bungeni Mapato na Matumizi ya Fedha kwa Mwaka 2015/2016. Dodoma: Bunge la Jamuhuri ya Muungano wa Tanzania.

URT (2015). The Ministry of Natural Resources and Tourism. Retrieved from www.mnrt.go.tz

URT (2015a). Hotuba ya Waziri wa Maliasili na Utalii Mh. Lazaro Samweli Nyarandu (Mb) Akiwasilisha Bungeni Mapato na Matumizi ya Fedha kwa Mwaka 2016/2017. Dodoma: Bunge la Jamuhuri ya Muungano wa Tanzania.

URT (2017). The 2016 Tourism statistical Bulletin. Dar es Salaam: Ministry of Natural Resources and Tourism.

WTTC (2012). Travel and Tourism Economic Impacts: Country Reports 2010. London: United Kingdom.

Evaristo Haulle is Senior Lecturer at the Department of Geography, Faculty of Humanities and Social Sciences, Mkwawa University College of Education, University of Dar es Salaam, Tanzania.

Contact Address: P.O. Box 2513, Iringa, Tanzania. Email: haulledict@gmail.com 